\title{
Overweight condition and waist circumference and a candidate gene within the 12q24 locus
}

Claudia Gragnoli, ${ }^{1,2,3}$

\begin{abstract}
Aims: Obesity and obesity-associated phenotypes are linked to the chromosome12q24 locus, the non-insulindependent-diabetes 2 (NIDDM2) locus. The gene of proteasome modulator 9 (PSMD9) lies in the NIDDM2 region and is linked to type 2 diabetes (T2D), microvascular and macrovascular complications of T2D.

We aimed at studying whether the PSMD9 T2D risk single nucleotide polymorphisms (SNPs) IVS3+nt460, INS3+nt437, and $197 \mathrm{G}$ are linked to obesity, overweight status and waist circumference in Italian T2D families.

Methods and results: We screened 200 Italians T2D siblings/families for PSMD9 variants. Using Merlin software, we performed non-parametric linkage analysis to test for linkage with obesity and overweight condition and variance component analysis to test for linkage with waist circumference in our T2D siblings/families dataset.

Our study shows that the PSMD9 SNPs IVS3+nt460, IVS3+nt437, and 1976 are in linkage with overweight condition and waist circumference in Italians. The statistical power tests performed via simulations on real data confirm that the results are not due to random chance.

Conclusions: In summary, the linkage strategy using a homogeneous family/subject dataset can identify a gene contributing to a complex trait. PMSD9 may be at least one of the genes responsible for the linkage to obesity and obesity-associated phenotypes at the locus 12q24 in other populations.
\end{abstract}

Keywords: PSMD9, SNP, Linkage, 12q24, Overweight, Waist

\section{Introduction}

Several groups reported linkage within the NIDDM2 (noninsulin-dependent diabetes mellitus) locus at chromosome 12q24 to T2D, obesity, central fat mass and waist circumference [1-8]. Within the 12q24 locus lies the gene of proteasome modulator 9 (PSMD9), a transcriptional regulator of the insulin gene, highly expressed in pancreatic islets [9]. PSMD9 is a ubiquitous protein of eukaryotic cells and part of the $26 \mathrm{~S}$ proteasome complex, contributing to intracellular proteins degradation into antigenic peptides in the immune response to antigen presentation by MHC class I cells (www.genecards.org/cgi-bin/carddisp.pl?gene=PSMD9). PSMD9 may play a role in inflammation as part of the autoimmune process [10]. Further, PSMD9 regulates the

\footnotetext{
Correspondence: claudia.gragnoli@gmail.com

${ }^{1}$ Laboratory of Molecular Genetics of Complex and Monogenic Disorders, Department of Medicine and Cellular \& Molecular Physiology and Biostatistics, M. S. Hershey Medical Center, Penn State University College of Medicine, Hershey, PA, USA

${ }^{2}$ Center for Biotechnology and Department of Biology, Temple University's College of Science \& Technology, Philadelphia, PA, USA

Full list of author information is available at the end of the article
}

transcription of the ligand-dependent retinoid-target genes (www.millipore.com/pathways/pathviewer.do?pathwayld=76). Since PSMD9 is a coactivator of insulin gene transcription [9], and in pancreatic overexpression of transgenic mice cause diabetes [11], PSMD 9 variants may contribute to T2D as well as to obesity, overweight status and visceral obesity.

We reported that PSMD9 may rarely cause T2D by unique mutations [12] and that is linked to T2D [13], maturity-onset diabetes of the young 3 (MODY3) [14], T2D-microvascular [15-18] and T2D-macrovascular complications [19], hypercholesterolemia [20], hypertension [21], carpal tunnel syndrome [22], and depression [23]. Of note, the $12 \mathrm{q} 24$ locus is not only linked to T2D [24], macrovascular [25,26] and microvascular disease [27], but also to dyslipidemia [28], hypertension, obesity, [2], body mass index and C-reactive protein jointly [29], cat-specific IgE and total IgE in asthma [30], and most interestingly to bipolar disorder [31] and depression [32]. Also a recent study has reported that a deletion at the locus $12 \mathrm{q} 24.33$ is significantly correlated with height, suggesting that this 
locus is important in determining height and may contribute to height variation in human populations [33].

The aim of the present study is to identify whether PSMD9 IVS3+nt460, IVS3+nt437, and 197G single nucleotide polymorphisms (SNPs) may be linked to maximum lifetime obesity, maximum lifetime overweight status and visceral obesity measured by waist circumference in an Italian family dataset.

\section{Methods}

\section{Ethics statement}

The subjects were all recruited from center Italy following the Helsinki declaration guidelines. Subjects gave written informed consent and the Penn State College of Medicine Ethical Committee approved the study.

\section{Families}

We recruited 200 Italian T2D affected siblings and families. We excluded all families with identical twins and confirmed that at least three generations were Italian. Italians are a homogeneous population living in a peninsula and they are suitable for genetic studies due to lack of genetic admixture. This family dataset has helped studying and identifying T2D and MODY genes contributing to disease [34-48].

\section{Clinical phenotyping}

We characterized the Italian families for maximum lifetime body mass index $\left[\mathrm{BMI}=\right.$ weight in $\mathrm{Kg} /(\text { height in } \mathrm{m})^{2}$ ], indicating as overweight those with maximum lifetime BMI $\geq 25$ and as obese those with maximum lifetime $\mathrm{BMI} \geq 30$. We measured also the waist circumference in $\mathrm{cm}$. BMI and waist circumference during pregnancy in females were not considered. Phenotypes are described as unknown if diagnosis is unclear because data are lacking. In our 200 Italian families, data are less than $100 \%$ for each phenotype.

\section{Sequencing}

Via PCR, we amplified with specific primers in the affected and unaffected family members the IVS3 PSMD9 region containing the $+n t 460 A / G$ and $+n t 437 C / T$ SNPs and the exon 5 coding region containing the E197G A/G SNP. We directly sequenced the PCR products, status post-purification via EXOSAP-IT on an automated ABI 3730 Sequencer.

\section{Linkage analysis}

We tested in the 200 Italians families for linkage of the PSMD9 SNPs with maximum lifetime obesity, maximum lifetime overweight condition and waist circumference.

The non-parametric linkage analysis for the qualitative phenotypes and the variance component analysis for the quantitative trait were performed by using Merlin software [49], calculating the allelic frequency from the total 200 genotyped families. Merlin analyzed all the informative families within this dataset. All results are reported as LOD scores calculated by Merlin.

\section{Simulations}

For each test performed, to exclude the presence of any results due to random chance, we calculated how many times similar P-values were expected by chance in 1,000 replicates of simulations by using the gene dropping method: this analysis replaces real data with simulated data, while maintaining the pedigree structure, allele frequencies and recombination fraction. These datasets are generated under the null hypothesis of no linkage.

\section{Results}

The results (LOD score, P-value and empirical P-value) of the non-parametric linkage analysis performed for the qualitative phenotypes overweight status and obesity are shown in Table 1.

The results of the variance component analysis performed for the quantitative trait waist circumference in $\mathrm{cm}$ with the LOD score, $\mathrm{P}$-value, empirical P-value, trait heritability and trait heritability attributable to the SNPs under study are reported in Table 2.

\section{Discussion}

Our analyses show that the PSMD9 IVS3+nt460, IVS3 $+n t 437$, and $197 G$ SNPs are in linkage with maximum lifetime overweight and with waist circumference, representing visceral obesity. Further, there is a trend towards linkage with obesity. The reduced number of families meeting the criteria for obesity may have reduced the power to detect linkage.

The 12q24.2 chromosome bears the NIDDM2 locus, the MODY3 gene HNF-1 $\alpha$, cause of T2D and MODY3, respectively. We previously reported that unique rare PSMD9 mutations contribute to T2D and that the IVS3 $+n t 460$, IVS3+nt437, and $197 G$ SNPs are linked to T2D

Table 1 Non-parametric linkage analysis of phenotypes of the 200 Italian families by Merlin software

\begin{tabular}{lcccc}
\hline Phenotype & Prevalence & Families & Lod score & Empirical P-value \\
\hline Overweight & $85.20 \%$ & 112 & 1.22 & 0.004 \\
Obesity & $47.50 \%$ & 42 & 0.62 & 0.009 \\
\hline
\end{tabular}

Prevalence = phenotype prevalence among the family subjects studied; Families = families number analyzed; Lod score = derived from the non-parametric linkage analysis by Merlin; Empirical P-value = derived from 1000 replicates by using the gene dropping method; Overweight $=$ presence of $B M I \geq 25$; Obesity = presence of $\mathrm{BMI} \geq 30$. 
Table 2 Variance component linkage analysis of the waist circumference in $\mathrm{cm}$ of the 200 Italian families by Merlin software

\begin{tabular}{lcccccc}
\hline Quantitative trait & Families & Trait heritability & Gene trait heritability & Lod score & P-value & Empirical P-value \\
\hline Waist in cm & 108 & $50.66 \%$ & $49.17 \%$ & 0.93 & 0.020 & 0.023 \\
\hline
\end{tabular}

Families = families number analyzed; Lod score = derived from the quantitative trait analysis by Merlin; Empirical P-value = derived from 1000 replicates by using the gene dropping method; Trait Heritability = Heritability of the quantitative trait calculated by Merlin; Trait Heritability attributable to the PSMD9 SNPs.

and MODY3 in our Italian dataset [12,13,14]. Of note, PSMD9 linkage to micro- and macro-vascular disease of T2D [15-19], hypercolesterolemia [20], hypertension [21] and depression [23] suggest a potential role in mediating an inflammatory response, which could explain the presence of linkage to the obesity-associated phenotypes.

Our results demonstrating the presence of linkage to overweight condition as well as to waist circumference are encouraging as the same locus is in linkage in other populations with obesity, central fat mass and waist circumference $[1,2,8]$. The data should be replicable in other ethnic groups and are of high interest to the groups who revealed linkage in the same locus, which may be explained by the PSMD9 variants.

In addition, we again prove the strength and validity of the linkage approach in identifying genes in complex disorders. In fact, family-based linkage studies are safer in their statistical nature compared to association studies. Also, we consider that the use of microsatellites as markers in the past may have negatively affected the results of the linkage, especially in polygenic diseases and with the use of affected siblings, as these markers may undergo duplications and mutations in vivo. In fact, previously we could not identify linkage with T2D at 12 q24 using multiple highly informative and polymorphic microsatellites within the same family dataset (data not shown) in which the linkage was identified using SNPs [13]. Hence, SNP-based linkage studies are more reliable. Also, the family dataset should be ethnically homogenous to allow results to be revealed.

PSMD9 should be screened in other populations for mutations and common variants in families with obesity, overweight condition and visceral obesity.

Interestingly, the reported $12 \mathrm{q} 24$ locus linkage to catspecific IgE and total IgE in asthma [30] could offer a possible explanation of the pleiotropic effects of such locus. In fact, the identified 12q24 linkage to multiple disorders including T2D [24], micro- and macrovascular disease [25-27], hypertension [2], body mass index and C-reactive protein [29], dyslipidemia [28], depression [32] and bipolar disorder [31] supports the idea that there could be a common underlying pathogenetic factor triggering the above-mentioned multiple disorders, such as an exaggerated inflammatory response or a deregulated autoimmune response leading to disease status. And this hypothesis fits well with the role of PSMD9 in the proteasome complex $26 \mathrm{~S}$ processing the antigens for the immune response (www.genecards.org/cgi-bin/carddisp. pl?gene=PSMD9). PSMD9 may play an inflammatory role in autoimmunity [10] with pleiotropic effects. Of note, the finding that 12q24.33 deletion affects height [33] could represent an outcome of the inheritance of factors predisposing to pre-disease states and thus affecting adult final growth. In fact, height is inversely associated with cardiovascular disease [50] and cardiovascular risk factors, such as insulin resistance [51]. Thus, the 12q24 locus could bear the gene or genes contributing to waist circumference, insulin resistance, cardiovascular disease, depression and height determination. It would be of interest to study the role of PSMD9 in asthma and IgE-mediated disorders as well as in final adult height.

\section{Competing interest}

The author has not conflict of interest to declare.

\section{Acknowledgments}

Special thanks go to the Molecular Biology staff of Bios Biotech MultiDiagnostic Health Center (Rome, Italy), which has provided technical as well as financial support for this study.

\section{Funding}

This work was supported by Penn State College of Medicine.

\section{Author details}

${ }^{1}$ Laboratory of Molecular Genetics of Complex and Monogenic Disorders, Department of Medicine and Cellular \& Molecular Physiology and Biostatistics, M. S. Hershey Medical Center, Penn State University College of Medicine, Hershey, PA, USA. ${ }^{2}$ Center for Biotechnology and Department of Biology, Temple University's College of Science \& Technology, Philadelphia, PA, USA. ${ }^{3}$ Molecular Biology Laboratory, Bios Biotech Multi-Diagnostic Health Center, Rome, Italy.

Received: 19 December 2012 Accepted: 28 December 2012 Published: 3 January 2013

\section{References}

1. Cornes BK, Medland SE, Ferreira MA, Morley Kl, Duffy DL, Heijmans BT, Montgomery GW, Martin NG: Sex-limited genome-wide linkage scan for body mass index in an unselected sample of 933 Australian twin families. Twin Res Hum Genet 2005, 8:616.

2. Wilson SG, Adam G, Langdown M, Reneland R, Braun A, Andrew T, Surdulescu GL, Norberg M, Dudbridge F, Reed PW, Sambrook PN, Kleyn PW, Spector TD: Linkage and potential association of obesity-related phenotypes with two genes on chromosome 12q24 in a female dizygous twin cohort. Eur J Hum Genet 2006, 14:340.

3. Demenais F, Kanninen T, Lindgren CM, Wiltshire S, Gaget S, Dandrieux C, Almgren P, Sjogren M, Hattersley A, Dina C, Tuomi T, McCarthy MI, Froguel P, Groop LC: A meta-analysis of four European genome screens (GIFT Consortium) shows evidence for a novel region on chromosome 17p11.2-q22 linked to type 2 diabetes. Hum Mol Genet 2003, 12:1865.

4. Shaw JT, Lovelock PK, Kesting JB, Cardinal J, Duffy D, Wainwright B, Cameron DP: Novel susceptibility gene for late-onset NIDDM is localized to human chromosome 12q. Diabetes 1998, 47:1793.

5. Wiltshire S, Frayling TM, Groves CJ, Levy JC, Hitman GA, Sampson M, Walker M, Menzel S, Hattersley AT, Cardon LR, McCarthy MI: Evidence from a large 
U.K. family collection that genes influencing age of onset of type 2 diabetes map to chromosome $12 p$ and to the MODY3/NIDDM2 locus on 12q24. Diabetes 2004, 53:855.

6. Reynisdottir I, Thorleifsson G, Benediktsson R, Sigurdsson G, Emilsson V, Einarsdottir AS, Hjorleifsdottir EE, Orlygsdottir GT, Bjornsdottir GT, Saemundsdottir J, Halldorsson S, Hrafnkelsdottir S, Sigurjonsdottir SB, Steinsdottir S, Martin M, Kochan JP, Rhees BK, Grant SF, Frigge ML, Kong A, Gudnason V, Stefansson K, Gulcher JR: Localization of a susceptibility gene for type 2 diabetes to chromosome 5q34-q35.2. Am J Hum Genet 2003, 73:323.

7. Bowden DW, Sale M, Howard TD, Qadri A, Spray BJ, Rothschild CB, Akots G, Rich SS, Freedman BI: Linkage of genetic markers on human chromosomes 20 and 12 to NIDDM in Caucasian sib pairs with a history of diabetic nephropathy. Diabetes 1997, 46:882.

8. Dong C, Li WD, Geller F, Lei L, Li D, Gorlova OY, Hebebrand J, Amos Cl, Nicholls RD, Price RA: Possible genomic imprinting of three human obesity-related genetic loci. Am J Hum Genet 2005, 76:427.

9. Thomas MKYK, Tenser MS, Wong GG, Habener JF: Bridge-1, a novel PDZdomain coactivator of E2A-mediated regulation of insulin gene transcription. Mol Cell Biol 1999, 19:8492.

10. Wick G, Millonig G, Xu Q: The autoimmune pathogenesis of atherosclerosis-an evolutionary-Darwinian concept. Atherosclerosis and Autoimmunity 2001, Section V:5.

11. Volinic JL, Lee JH, Eto K, Kaur V, Thomas MK: Overexpression of the coactivator bridge-1 results in insulin deficiency and diabetes. $\mathrm{Mol}$ Endocrinol 2006, 20:167.

12. Gragnoli C, Cronsell J: PSMD9 gene variants within NIDDM2 may rarely contribute to type 2 diabetes. J Cell Physiol 2007, 212:568-571.

13. Gragnoli C: PSMD9 gene in the NIDDM2 locus is linked to type 2 diabetes in Italians. J Cell Physiol 2010, 222:265.

14. Gragnoli C: PSMD9 is linked to MODY3. J Cell Physiol 2010, 223:1.

15. Gragnoli C: Proteasome modulator 9 is linked to microvascular pathology of T2D. J Cell Physiol 2012, 227(8):3116-3118.

16. Gragnoli C: Proteasome Modulator 9 Gene is Linked to Diabetic and Non-Diabetic Retinopathy in T2D. Ophthalmic Genet 2011, 2011 Jul 5. [Epub ahead of print].

17. Gragnoli C: PSMD9 is linked to type 2 diabetes neuropathy. $J$ Diabetes Complications 2011, 25:329.

18. Gragnoli C: T2D-nephropathy linkage within $12 q 24$ locus. Diabetes Res Clin Pract 2011, 92:e73

19. Gragnoli C: Proteasome modulator 9 and macrovascular pathology of T2D. Cardiovasc Diabetol 2011, 10:32.

20. Gragnoli C: Hypercholesterolemia and a candidate gene within the 12q24 locus. Cardiovasc Diabetol 2011, 10:38.

21. Gragnoli C: Proteasome modulator 9 SNPs are linked to hypertension in type 2 diabetes families. Cardiovasc Diabetol 2011, 10:77.

22. Gragnoli C: Proteasome modulator 9 and carpal tunnel syndrome. Diabetes Res Clin Pract 2011, 94:e47.

23. Gragnoli C: Proteasome modulator 9 and depression. Curr Med Chem 2012, 19(30):5178-5180.

24. Mahtani MM, Widen E, Lehto M, Thomas J, McCarthy M, Brayer J, Bryant B, Chan G, Daly M, Forsblom C, Kanninen T, Kirby A, Kruglyak L, Munnelly K, Parkkonen M, Reeve-Daly MP, Weaver A, Brettin T, Duyk G, Lander ES, Groop LC: Mapping of a gene for type 2 diabetes associated with an insulin secretion defect by a genome scan in Finnish families [see comments]. Nat Genet 1996, 14:90.

25. Erdmann J, Grosshennig A, Braund PS, Konig IR, Hengstenberg C, Hall AS, Linsel-Nitschke P, Kathiresan S, Wright B, Tregouet DA, Cambien F, Bruse P, Aherrahrou Z, Wagner AK, Stark K, Schwartz SM, Salomaa V, Elosua R, Melander O, Voight BF, O'Donnell CJ, Peltonen L, Siscovick DS, Altshuler D, Merlini PA, Peyvandi F, Bernardinelli L, Ardissino D, Schillert A, Blankenberg S, Zeller T, Wild P, Schwarz DF, Tiret L, Perret C, Schreiber S, El Mokhtari NE, Schafer A, Marz W, Renner W, Bugert P, Kluter H, Schrezenmeir J, Rubin D, Ball SG, Balmforth AJ, Wichmann HE, Meitinger T, Fischer M, Meisinger C, Baumert J, Peters A, Ouwehand WH, Deloukas P, Thompson JR, Ziegler A, Samani NJ, Schunkert H: New susceptibility locus for coronary artery disease on chromosome 3q22.3. Nat Genet 2009, 41:280.

26. Sherva R, Miller MB, Pankow JS, Hunt SC, Boerwinkle E, Mosley TH, Weder $A B$, Curb JD, Luke A, Morrison AC, Fornage M, Arnett DK: A whole-genome scan for stroke or myocardial infarction in family blood pressure program families. Stroke 2008, 39:1115.
27. Ikram MK, Xueling S, Jensen RA, Cotch MF, Hewitt AW, Ikram MA, Wang J,, Klein R, Klein BE, Breteler MM, Cheung N, Liew G, Mitchell P, Uitterlinden AG, Rivadeneira F, Hofman A, de Jong PT, van Duijn CM, Kao L, Cheng CY, Smith AV, Glazer NL, Lumley T, McKnight B, Psaty BM, Jonasson F, Eiriksdottir G, Aspelund T, Harris TB, Launer LJ, Taylor KD, Li X, lyengar SK, Xi Q, Sivakumaran TA, Mackey DA, Macgregor S, Martin NG, Young TL, Bis JC, Wiggins KL, Heckbert SR, Hammond CJ, Andrew T, Fahy S, Attia J, Holliday EG, Scott RJ, Islam FM, Rotter Jl, McAuley AK, Boerwinkle E, Tai ES, Gudnason V, Siscovick DS, Vingerling JR, Wong TY: Four novel Loci $(19 q 13,6 q 24,12 q 24$, and 5q14) influence the microcirculation in vivo. PLoS Genet 2010, 6:e1001184

28. Aberg K, Dai F, Sun G, Keighley E, Indugula SR, Bausserman L, Viali S, Tuitele J, Deka R, Weeks DE, McGarvey ST: A genome-wide linkage scan identifies multiple chromosomal regions influencing serum lipid levels in the population on the Samoan islands. J Lipid Res 2008, 49:2169.

29. Wu J, Pankow JS, Tracy RP, North KE, Myers RH, Feitosa ME, Province MA, Borecki IB: QTL on 12q influencing an inflammation marker and obesity in white women: the NHLBI family heart study. Obesity (Silver Spring) 2009, 17:525.

30. Gusareva ES, Bragina EJ, Buinova SN, Chernyak BA, Puzyrev VP, Ogorodova LM, Lipoldova M: Chromosome 12q24.3 controls sensitization to cat allergen in patients with asthma from Siberia, Russia. Immunol Lett 2009, 125:1.

31. Cassidy F, Zhao C, Badger J, Claffey E, Dobrin S, Roche S, McKeon P: Genome-wide scan of bipolar disorder and investigation of population stratification effects on linkage: support for susceptibility loci at 4q21, 7q36, 9p21, 12q24, 14q24, and 16p13. Am J Med Genet B Neuropsychiatr Genet 2007, 144B:791.

32. Christiansen L, Tan Q, Kruse TA, McGue M, Christensen K: Candidate region linkage analysis in twins discordant or concordant for depression symptomatology. Am J Med Genet B Neuropsychiatr Genet 2009, 150B:581.

33. Kim YK, Moon S, Hwang MY, Kim DJ, Oh JH, Kim YJ, Han BG, Lee JY, Kim BJ: Gene-based copy number variation study reveals a microdeletion at 12q24 that influences height in the Korean population. Genomics 2012, pii: S0888-7543(12):00210-8.

34. Gragnoli C, Cockburn BN, Chiaramonte F, Gorini A, Marietti G, Marozzi G, Signorini AM: Early-onset Type II diabetes mellitus in Italian families due to mutations in the genes encoding hepatic nuclear factor 1 alpha and glucokinase. Diabetologia 2001, 44:1326.

35. Milord E, Gragnoli C: Chromosome 10 locus in linkage to type 2 diabetes in Italians. Obesity and Metabolism 2007, 3:44.

36. Godart F, Bellanne-Chantelot C, Clauin S, Gragnoli C, Abderrahmani A, Blanche $H$, Boutin P, Chevre JC, Froguel P, Bailleul B: Identification of seven novel nucleotide variants in the hepatocyte nuclear factor-1alpha (TCF1) promoter region in MODY patients. Hum Mutat 2000, 15:173.

37. Gragnoli C, Menzinger Von Preussenthal G, Habener JF: Triple genetic variation in the HNF-4alpha gene is associated with early-onset type 2 diabetes mellitus in a philippino family. Metabolism 2004, 53:959.

38. Gragnoli C, Milord E, Habener JF: Linkage study of the glucagon receptor gene with type 2 diabetes mellitus in Italians. Metabolism 2005, 54:786.

39. Gragnoli C, Stanojevic V, Gorini A, Von Preussenthal GM, Thomas MK, Habener JF: IPF-1/MODY4 gene missense mutation in an Italian family with type 2 and gestational diabetes. Metabolism 2005, 54:983.

40. Milord E, Gragnoli C: NEUROG3 variants and type 2 diabetes in Italians. Minerva Med 2006, 97:373.

41. Meenakshisundaram R, Piumelli N, Pierpaoli L, Gragnoli C: CHOP 5/UTRc. $279 \mathrm{~T}>\mathrm{C}$ and $+\mathrm{nt} 30 \mathrm{C}>\mathrm{T}$ variants are not associated with overweight condition or with tumors/cancer in Italians-a case-control study. J Exp Clin Cancer Res 2009, 28:90.

42. Meenakshisundaram R, Piumelli N, Pierpaoli L, Gragnoli C: CDK4 IVS4nt40G->A SNP and type 2 diabetes in Italians. Diabetes Res Clin Pract 2009, 86:e28.

43. Meenakshisundaram R, Gragnoli C: CDK4 IVS4-nt40G->A and T2Dassociated obesity in Italians. J Cell Physiol 2009, 221:273.

44. Meenakshisundaram R, Gragnoli C: CDK4 IVS4-nt40 AA genotype and obesity-associated tumors/cancer in Italians - a case-control study. J Exp Clin Cancer Res 2009, 28:42.

45. Gragnoli C: CHOP T/C and C/T haplotypes contribute to early-onset type 2 diabetes in Italians. J Cell Physio/ 2008, 217:291.

46. Gragnoli C, Cronsell J: Meta-analysis of the IPF1 D76N polymorphism in a worldwide type 2 diabetes population. Minerva Med 2007, 98:163. 
47. Gragnoli C, Lindner T, Cockburn BN, Kaisaki PJ, Gragnoli F, Marozzi G, Bell Gl: Maturity-onset diabetes of the young due to a mutation in the hepatocyte nuclear factor-4 alpha binding site in the promoter of the hepatocyte nuclear factor-1 alpha gene. Diabetes 1997, 46:1648.

48. Gragnoli C, Pierpaoli L, Piumelli N, Chiaramonte F: Linkage studies for T2D in Chop and C/EBPbeta chromosomal regions in Italians. J Cell Physiol 2007, 213:552.

49. Abecasis GR, Cherny SS, Cookson WO, Cardon LR: Merlin-rapid analysis of dense genetic maps using sparse gene flow trees. Nat Genet 2002, 30:97.

50. Williams SR, Jones E, Bell W, Davies B, Bourne MW: Body habitus and coronary heart disease in men. A review with reference to methods of body habitus assessment. Eur Heart J 1997, 18:376.

51. Smith GD, Greenwood R, Gunnell D, Sweetnam P, Yarnell J, Elwood P: Leg length, insulin resistance, and coronary heart disease risk: the Caerphilly Study. J Epidemiol Community Health 2001, 55:867.

doi:10.1186/1475-2840-12-2

Cite this article as: Gragnoli: Overweight condition and waist circumference and a candidate gene within the 12q24 locus. Cardiovascular Diabetology 2013 12:2.

\section{Submit your next manuscript to BioMed Central and take full advantage of:}

- Convenient online submission

- Thorough peer review

- No space constraints or color figure charges

- Immediate publication on acceptance

- Inclusion in PubMed, CAS, Scopus and Google Scholar

- Research which is freely available for redistribution 